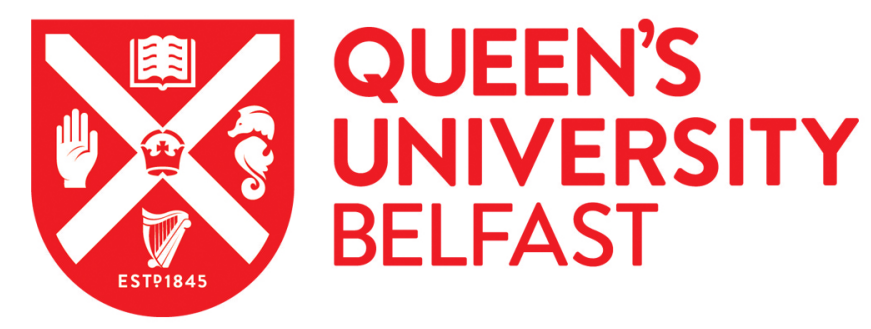

\title{
Powers of the Gun Process and Possibility in Global Small Arms Control
}

Bourne, M. (2018). Powers of the Gun Process and Possibility in Global Small Arms Control. International Politics, 55(3-4), 441-461. https://doi.org/10.1057/s41311-017-0080-6

\author{
Published in: \\ International Politics
}

\section{Document Version:}

Peer reviewed version

Queen's University Belfast - Research Portal:

Link to publication record in Queen's University Belfast Research Portal

\section{Publisher rights}

(c) 2017 Springer Nature.

This work is made available online in accordance with the publisher's policies. Please refer to any applicable terms of use of the publisher.

\section{General rights}

Copyright for the publications made accessible via the Queen's University Belfast Research Portal is retained by the author(s) and / or other copyright owners and it is a condition of accessing these publications that users recognise and abide by the legal requirements associated with these rights.

Take down policy

The Research Portal is Queen's institutional repository that provides access to Queen's research output. Every effort has been made to ensure that content in the Research Portal does not infringe any person's rights, or applicable UK laws. If you discover content in the Research Portal that you believe breaches copyright or violates any law, please contact openaccess@qub.ac.uk. 
POWERS OF THE GUN: PROCESS AND POSSIBILITY IN GLOBAL SMALL ARMS CONTROL ${ }^{i}$

\section{Mike Bourne}

Small Arms and Light Weapons (SALW) are the mundane material of armed violence. Firearms, for instance, are used in approximately 200,000 killings in crime and conflict each year (Geneva Declaration Secretariat, 2015). ${ }^{\text {ii }}$ SALW control is now central to Humanitarian Arms Control (HAC) that include bans on anti-personnel landmines (APM) and cluster munitions and emerging processes concerned with 'killer robots', depleted uranium, and nuclear weapons. Yet SALW control seeks to regulate (often minimally) rather than prohibit these weapons, with the reduction in the illicit trade (rather than the trade or use overall) being the principal aim - most recently emphasised in the inclusion of a target (16.4) of reducing illicit arms flows in the 2015 Sustainable Development Goals.

Global SALW control is not as a single unified regime but a 'regime complex' (Greene and Marsh 2012) consisting of numerous agreements at both global and regional levels. While the 2001 Firearms Protocol to the UN Convention against Transnational Organised Crime is legally binding, it is the politically binding 2001 UN Programme of Action to Prevent, Combat and Eradicate the Illicit Trade in Small Arms and Light Weapons in All Its Aspects (PoA) and related instruments that is most prominent. These, and many regional agreements, have produced widely varying 'norms' in different areas: with stronger and more detailed forms of action on the management of stockpiles and surplus arms, arms brokering, and marking and recordkeeping than on issues of transparency, and failed attempts to incorporate issues of civilian gun ownership or to ban arms transfers to non-state actors (Garcia, 2006). As it has developed it has forged links with other areas of practice such as Disarmament, Demobilisation and Reintegration (DDR), Security Sector Reform (SSR), wider armed 
violence reduction initiatives, and most recently the 2013 Arms Trade Treaty (ATT) which covers SALW among other conventional arms and so joins the global complex.

While some welcome HAC as evidence of 'moral progress' in international relations (Garcia, 2011); others highlight its conservative effects in preserving the power of western states while rendering pariah weapons and pariah actors (weak states, terrorists etc.) as targets of regulation (Cooper, 2011). Likewise, the processes of forming HAC are interpreted by some academics and participants as a contest between military necessity and morality; or between powerful states and transnational world of NGOs and their middle power allies; in which human security emerges victorious (Garcia, 2011; Wisotzki 2010). However, as with wider HAC, the clearest effect of global SALW control is the rearticulation and reinforcement of sovereignty: Agreements focus on illicit flows thereby legitimating state authorised trade and SALW themselves; and implementation reinforces sovereignty by seeking to standardise and enhance states' ability to control SALW stockpiles and flows. The legal trade in small arms and ammunition almost doubled in the decade after the PoA was agreed, from US\$2.38billion to US\$4.63billion (Holtom et-al, 2014). Even the ATT, which represents significant progress where the PoA failed by seeking responsibility within the legal trade, principally reinforces national decision-making.

The focus of much regime theory is the power to produce agreement, or at least to impose a settlement. The range of global agreements on SALW, and the PoA and wider UN process in particular, are often highlighted as weak with the measure of weakness relating to the linguistic ambiguity of their commitments, the exclusion of important issues, the lack of verification, limited legally rather than politically binding status, and often beleaguered political process. These weaknesses are claimed to result from the sheer diversity and complexity of issues and the material interests and preferences of powerful states and their 
exercise of compulsory power (Efrat, 2010; Garcia, 2011; Sears, 2012; Hansen, 2016). Conversely, others argue that the diversity of global and regional agreements and practices means that the 'regime complex' overall is stronger than its constituent parts - especially the PoA and UN process (Greene and Marsh, 2012) and that implementation has tended be stronger where regional and global frameworks converge (Bourne et-al, 2006). In both arguments, however, the strength or weakness of global instruments is explained by particular forms and loci of power. This is the trap identified by Latour (2005) that too often power is deemed the explanation of something, rather than itself being explained: power is deemed a cause but not an effect, thereby diminishing the politics in power politics and contributing to overemphasising the static over the dynamic in regime theory (Strange, 1982).

This article takes a different approach. Rather than explaining the relative strengths and weaknesses of a global SALW regime complex by identifying and asserting the importance of particular forms of power it seeks to use the case of SALW, and particularly the seemingly weak UN process, to engage in a different form of power analytics. To the literature on power and regimes it seeks to develop a different conceptualisation of forms of power by engaging new materialism and assemblage theories that enable an emphasis not only on the production of agreement but on the creation of possibilities and the proliferation of disagreements. After a brief sketch of the theoretical shifts entailed in this approach, the article then draws them through an analysis of the 'global assemblage' of SALW politics consisting of three interrelated registers that show how in spite of - indeed through - its inadequacies, global SALW politics constitutes the possibility of governing guns globally. These three registers focus on how power emerges as it creates the possibility to disagree by constituting political space; forms how agreement and disagreement are made meaningful and the process is sustained; and constitutes particular modes of action that make guns governable. It is important to note that the global politics of SALW is not posited as a unique case that shows that there are 
assemblages as well as regimes. The claim is not typological. Rather, the complexity, fragmentation, and unsettled character of global SALW politics presents an opportunity to see how power emerges as it constitutes the range of possibilities, meanings and practices that are indeterminate rather than determining and thus compose a different governing of guns.

\section{REASSEMBLING THE PROCESSES OF POWER}

Barnett and Duval (2005) and Hynek (in this special issue) enable recognition of the diversity of powers. In order to explore the composition of power, this article takes a further step in engaging the dynamism that underlies this diversity. The first section draws out a different orientation to forms of power inspired by process philosophy and recent developments in 'new materialist' thought. This engages how different forms of power are co-constitutive, such that power is not explained by arguing that one form or another explains an outcome but rather that they combine to form each other in composing an assemblage of powers. This allows the article to argue that global SALW control, and perhaps other 'regimes', are global assemblages defined not by the presence or lack of settled norms that diminish controversy, but that arise through multiplying and distributing controversies.

In pursuing power in this way this article seeks to move from a taxonomy of powers in global regimes to a topology of power in global assemblages. Taxonomy, for Barnett and Duval, is an attempt to 'carve power at its joints' by producing 'critical, mutually exclusive, and exhaustive distinctions.' (2005: 43). While this highlights the diversity of forms of power in operation, it cannot answer Latour's invitation to explain power since the production of forms of power is cut off by disjointing power: power forms may interact but not be co-constitutive in a deeper sense. Further, the taxonomy is defined by relations of distance and directness and interaction vs constitution which can downplay the emergent creation of space. In contrast, 
topology, for Serres, denotes the mapping of nearness and rifts not in geometric space but in the emergent relational space constituted by comings together, flows, modifications, and separations of issues, actors, practices etc. (Serres and Latour, 1995). These dynamic proximities and distances reveal power to be a 'composition': both as verb and noun denoting the process of creativity and the product (Latour 1986; 2005). Thus, power is an emergent effect of numerous comings together, of enrolling different actors, arguments, objects and so forth. Power exists only within a collective, and it is the collective that creates power and is also created by it. ${ }^{\text {iii }}$

In emphasising topology and composition this article is oriented towards assemblage thinking and its underpinnings in process philosophy. A process orientation does not distinguish between process (as negotiation in diplomatic fora etc.) and outcome (the 'norms', instruments, agreements, and settled practices) in the way the colloquial use of the term process may imply. Rather, Whitehead describes the 'principle of process' as 'how an actual entity becomes constitutes what that actual entity is...Its "being" is constituted by its “becoming.”” (1929/1978:23). Here the process of creation and the object created are both processes. No longer do we have the curious end to creation implied by ontologically distinguishing production from product, or object from its movement and meaning, as all are processes. Thus, norms are not stable objects that are built and then 'diffused' but are continuing processes. This helps avoid potentially misleading distinctions such as the claim that 'small states' and NGOs matter in processes but not in regulatory outcomes (Drezner, 2008). They may matter differently, but they are made to matter in the composition of assemblages. Rather than seeking to explain SALW politics by identifying power (of NGOs versus or with states etc.), this article seeks to understand power as it emerges. Here power is always an effect of associations, it is only ever power in action, not a reserve of power that is possessed, stored up and utilised (Latour, 1986). 
Assemblages are not merely strategic alliances of actors, through which power operates, nor fully unified wholes that eliminate diversity, but are collectives in which power and actors emerge and become relatively stabilised in their co-functioning (Deleuze and Parnet 2007). Global SALW politics can be understood not just as a complex of clusters of issues, agreements, and practices, but as a 'global assemblage' in Collier and Ong's terms: 'As a composite concept, the term “global assemblage”' suggests inherent tensions: global implies broadly encompassing, seamless, and mobile; assemblage implies heterogeneous, contingent, unstable, partial, and situated.' (2005: 12). Since 'the assemblage's only unity is that of cofunctioning: It is a symbiosis, a "sympathy”.' (Deleuze and Parnet 2007: 69) an assemblage is an achievement that does not need to overcome diversity of complexity, but merely to make co-functioning possible. Thus the strength of unity (effectiveness in tackling the problem is a different question) of regimes lies not merely in a high degree of specificity, institutionalisation, or normative and epistemic concurrence but in the ability to render functionally coherent still disparate issue frames, priorities, capacities etc. Such a functional unity of disparate elements is an emergent property of the process of assemblage in which controversies remain and indeed proliferate.

Controversies are assemblages in which disagreements are not resolved but moved, enrolled, channelled, and ultimately expanded. ${ }^{\text {iv }}$ They are not just events or debates that occur within a pre-given collective or location but rather produce their own scales, locations, temporalities etc. that shift, appear and disappear, stabilise and destabilise, since these emerge immanently (Stengers, 2000; Barry, 2013). Rather than following Barnett and Duval's distinction between powers that operate in interactions of 'preconstituted actors' and those operative in 'social relations of constitution' (2005: 45), the approach here echoes Barad's (2007) notion of ‘intra-action' in which entities (here actors and powers) are not simply inter-active but always co-constitutive, becoming together. ${ }^{\mathrm{v}}$ Thus what is often registered as compulsory power and 
institutional power (that are relatively stable) must be viewed as a circulation of powers whose stabilisation needs to be explained. Likewise, while their taxonomy characterises productive power as the indirect production of subjective identities of human actors, a process/assemblage view allows this article to try to register the far wider sense of productivity at play in SALW control: the production of possibilities, powers and modes of action.

\section{MAKING DISAGREEMENT POSSIBLE: EXPERTISE, RE-PRESENTATION, AND THE COMPOSITION OF POWERS}

How do SALW become a global political issue? As Garcia argues, while the Ottawa process on APM coalesced around clear goals and strong leadership to form a unified 'norm-building pathway' the SALW process was more fragmented in its goals, leadership and issue framings (2006: 26). If issue complexity, diverse interests and problem framings, resist regime formation then how did it become possible to speak of a global SALW politics at all? It is common to argue that this relates to norm entrepreneurship and awareness raising. However, the former only asks what how agreement is forged out of disagreement; and the latter implies that agreement is forged within a pre-existing international community who were made aware of a problem. Further, in the SALW case and in much transnational governance, both are commonly argued to arise through the efforts of NGOs, experts, and International Organisations. However, no single actor or power type was the origin of the SALW agenda: The importance of NGOs and researcher expertise, for instance, has sometimes followed rather than led inter-governmental events and actions, and many key agreements such as the UN Firearms Protocol and some early regional agreements like the 1997 OAS convention, ${ }^{\mathrm{vi}}$ involved relatively little NGO action (Krause 2001). 
The approach outlined above reframes this question in an important way: How did it become possible to disagree globally about SALW? Composing collective action is principally the process of constituting collectives, or even 'publics' (Marres, 2007; Walters and D’Aoust, 2015). Indeed, for Barry 'in politics the collective is not a given, but an entity in process' (2002: 271). In this sense the composition of a collective and that of a controversy are the same - global SALW politics becomes possible by composing a novel global political space. The key feature of this political space is that it multiplies possibilities for disagreement: As Barry argues, '[t]he construction of new forms of transnational governance is not based on a stable infrastructure, but on an informational infrastructure that continues to generate new matters about which it is possible to disagree.' (2012: 333, Emphasis added). Assembling the possibility to disagree, the infrastructure of disagreement as well as its content, is the process of translating distant and particular events (in both time and space) into a global politics. While principally an operation of productive power, it emerges through intra-actions of other powers as it draws together and modifies other controversies and settlements.

This shifting topology of powers can be seen in the co-emergence of issue framings, actor authority, forms of evidence, categories and distinctions that serve as working objects around which a politics can emerge. In terms of forms of evidence, in some fields experimental data and abstract models (e.g. climate change) or quasi-experimental methods (game theoretic productions of nuclear deterrence) have become influential of the mode of disagreement. In early HAC, however, experimental evidence proved inconclusive and divisive (Prokosch, 1995), and for landmines, evidence derived from experience (of deminers, doctors, and mine victims) was combined with the ICRC's authority on international law to enable campaigners to overcome abstract models of military experts with the testimony of 'compelling spokespersons who could not be easily dismissed' (Hubert, 2000: 31; Borrie 2009). Early SALW debates, in the mid-1990s, established similar modes of evidence and authority based 
on experiential rather than experimental evidence of abstract modelling. Notably, however, these were framed in less oppositional terms - not least because the inherent lethality of the weapons themselves was not permitted to become the focus of concern, but rather their abundance and easy portability enabling illicit flows. Early researcher engagement sought to distinguish SALW from major conventional arms both in terms of their categorisation and effects through case study research focussed on conflict (initially on Afghanistan, Colombia, Pakistan, and Somalia). These generated evidence of consequences that resonated with notions of 'flow out of control' (Krause, 2001) and wider geopolitical imaginations centring on failed state problematiques. Here, however, UN experience and expertise as much as that of independent researchers and NGOs, produced the dominant framing as Boutros-Ghali's call for 'micro-disarmament' in the supplement to the Agenda for Peace, and reports on Mali and the wider Sahara-Sahel, consolidated understandings of what count as SALW, and set out links between security and development, distinctions between illicit and licit transfers, an emphasis on surplus weapons destruction and disposal, and marking issues (Krause, 2001; Laurance 2014). These characteristic relationships and distinctions still persist as a dominant framing.

The construction of the possibility to disagree is not an ex-nihilo creation, but an assembling and recasting of other things. Some studies of norms argue that their diffusion is shaped by a key measure of their legitimacy and strength: that of their coherence with the 'genotype' of existing norms (Florini, 1996: 376). While such claims focus on later diffusion stages of norm life-cycles, such coherence with genotype is arguably important in forming the possibility to disagree. For instance, in APM negotiations coherence with genotypes of International Humanitarian Law produced a common legal vocabulary for disagreement (Mathur, 2012). In SALW, while Garcia argues that there was 'no previously existing enabling normative framework' to aid norm diffusion (2006: 23), there were strong 
genotypes that were drawn in to form the possibility of disagreement on SALW. Indeed, it was through such an inheritance that the category of SALW was produced: The five categories of Major Conventional Arms in the 1980 CFE treaty were utilised and extended in the seven covered by the 1998 UN Register of Conventional Arms; SALW became unified as a residual category in the groups of experts preparing for the 2001 UN Conference (the PoA contains no definition) and then became a further category for UN register reporting in 2003; and the 2013 ATT adopted all eight.

The principal 'genotype' of the SALW assemblage was a particular technocratic practice of expert engagement and its connection with established understandings of sovereignty. Sovereignty sets the limits of the SALW assemblage through explicit and frequent reference to the primacy of the UN Charter right to self-defence in government statements, UN documents etc. within the UN SALW process and the subsequent ATT negotiations. It is also an operative logic in which wider notions of sovereign decision-making and effective authorisation form the dominant understanding of the content of the distinction between licit and illicit flows. This demonstrates the productive power of categories and settled assumptions to establish operative distinctions, but this became a structural power of hegemonic framing. Indeed, even NGO and researcher expert knowledge, with its 'seemingly progressive categories and concepts' (Stavrianakis, 2011: 142) had to be framed to resonate with, and ultimately accept, familiar power-relations and reinforce a traditional understanding of armed violence and its management through international cooperation, and on the basis of broad assumptions of legitimacy of arms transfers and the use of force (Borrie, 2009; Krause, 2011; Rogers 2009).

In translating these seemingly settled principles into operative distinctions between weapons, status of flows etc. the assemblage also imports and remobilises disagreements. Thus, PoA 
debates over banning or controlling transfers to non-state actors continuously remobilised and reframed wider tensions between legal principles of territorial integrity and selfdetermination. Similarly, tensions between understandings of sovereignty, and between IHL and existing arms export deals or defence cooperation agreements produced much debate and uncomfortable compromises in the negotiations of the ATT (Hofman and Wisotzki, 2014; McDonald, 2013). Thus the genotype is not a static and stable normative background, but rather is mobilised and rearticulated as a combination of agreements and disagreements enabling proliferating controversies.

Making disagreement possible through the connections and cuts outlined here shifts the question of power away from assessing the relative power possessed by states, NGOs, IO, and researchers towards the ways in which power emerges through establishing proximities, sympathies, through what literature on expertise calls 'boundary work’ (Eyal and Pok, 2015). This locates power as an effect of and operative within networks of expertise that are themselves powerful. In the SALW assemblage, forms of power operative within the possibility to disagree arise particularly through the circulations and accumulations of information. Since the possibility to disagree is an informational infrastructure it can be argued to be inherently related to the emergence of power, echoing Rose and Miller's argument that government depends on information being 'trans-ported and accumulated in locales' which makes actors powerful as they can claim 'legitimacy for their plans and strategies because they are, in a real sense, in the know about that which they seek to govern' (1992: 185). Such knowledge and information must be materialised, inscribed, to be durable and powerful, and also to circulate. Such inscriptions may have a life of their own: Numbers, such as the estimate that there are 900million small arms in global circulation, does not merely reflect the power of the researchers that produce it (SAS) but also vice versa as experts benefit from the circulatory power of numbers (they are relatively immutable as they 
move - a function of their universal language, air of precision, and affective capacity) (Hansen and Porter, 2012).

The centralisation of technical knowledge, information, and legal authority is often seen as a source of the 'autonomous significance' and 'compulsory power' of International Organisations (whereas the use of compulsory power by NGOs derives from normative authority in 'shaming' states) (Barnett and Finnemore, 1999; Barnett and Duval, 2005). However, in the SALW assemblage circulations and accumulations of information have produced relations of mutual authorisation rather than 'autonomous significance'. The circulation and accumulation of inscriptions (numbers, anecdotes, case studies, best practices, draft outcome documents etc.) enabled the emergent assemblage of 'sympathetic' relations of mutual authorisation between researchers, NGOs, particular states, and the UN. The Small Arms Survey (SAS) has become a central authority of research expertise (its publications are among the only sources cited in UN resolutions and documents) by producing and contracting expert researchers and consolidating and circulating research outputs into annual yearbooks and a series of other publications. Conversely, the UN SALW process has shaped the agenda and contributed to the professionalization of small arms research (Laurance, 2014). The influence of the research community has been greatest on issues that the UN process prioritises (tracing, illicit brokering, stockpile management) and significantly less on issues of control of ammunition, regulating civilian possession, and monitoring implementation that have proven controversial (McDonald, 2014). Similarly, power hierarchies within NGO networks, such as the International Action Network on Small Arms (IANSA) were significantly shaped by the UN Process, and those closest to major states and UN bodies (receiving funding and support for their research and informal diplomatic activities: such as SAS and the Biting the Bullet project) gained greatest influence - thereby contributing to framing the agenda of NGOs in terms of conflict and weak states and 
downplaying domestic gun control organisations (Grillot et al, 2006). Some explicit articulations of these relations of mutual authorisation are also assertions of institutional power. For instance, upon the adoption of the ATT in 2013 UN Secretary General Ban KiMoon highlighted the 'expertise and enthusiastic support' of NGOs and that it demonstrated that 'great things that can be achieved when Governments and civil society work together through the United Nations.' (UN, 2013). Such mutual authorisation is also a feature of anticontrol networks. Anti-control groups such as the US National Rifle Association (NRA), attempted to discursively connect UN processes concerned principally with conflict to domestic gun regulation agendas. While the ‘facts' of this connection are not compelling (the PoA contains minimal reference to civilian possession - due in part to NRA and related campaigning in the early years) the agenda remains partly shaped by this attempt. This early campaigning was enhanced by NRA representatives being part of the official US delegation to the 2001 conference, and drawing from differing sources of moral and legal authority (Bob, 2015).

Overall, the actors and forms of power that are important are not pre-given but emerge with the topology of an assemblage, in particular as expertise and authority and working objects (categories, distinctions, forms of evidence) are constituted by forging or cutting off particular connections. These constitute the possibility of disagreement but this is a continuous process, coexistent with the circulations and sympathies that make agreement possible and the status of agreement and disagreement meaningful.

MAKING AGREEMENT POSSIBLE: CONSENSUS, TECHNICS, AND THE MEANING OF DECISION 
Assembling agreements may not be production of homogenous consensus but an emergent functional unity premised on the proliferation of controversies (Barry, 2012). It may be thought, at this point, that by following the circulations and accumulations of information and authority a picture emerges in which some actors (researchers and NGOs) inform and others (states) decide. Certainly, while a particular configuration of states, International Organisations, researchers and NGOs was important in calling for a UN Conference on SALW, it was the Panel of Governmental Experts (1997) and Group of Governmental Experts (1999) that were able to make this recommendation. Likewise it is states, within institutional contexts, that agree or fail to agree on outcomes of negotiations. It remains, therefore, via states' claims to authority and expertise that the SALW assemblage was created. However, a process orientation also reveals a set of functional symbioses which neither operate on the basis of this divide nor entirely erase it. In Whitehead's process philosophy '[t]he word "decision” does not...imply conscious judgement, though in some "decisions" consciousness will be a factor. The word is used in its root sense of a "cutting off”' (Whitehead, 1929: 43). The route of becoming is decided through actions that are cuts in different possible paths made within the process. This gives a broader connotation to the consolidation of decision-making procedures and trajectories that Barnett and Duvall consider as part of institutional power.

The act of decision is not simply an action of compulsory power within procedures established in institutional power but rather an emergent effect of the combination of forms of power. On the first day of the 2001 UN Conference, US representative John Bolton appeared to enact compulsory power when he drew a 'red line' against any coverage of civilian possession or transfers to non-state actors. This meant that after Bolton's speech 'the conference was, for all practical purposes, completely over' (Karp 2002:177) and it 'ensured the evisceration of any resulting instrument' (Mutimer, 2006: 30). Yet in enacting such a 
decisive cut Bolton assembled numerous powers: In seeking to restrict scope to 'military' SALW he invoked and unified a combination of a national 'cultural tradition of hunting and sport shooting', a domestic legal position by quoting U.S. Attorney General Ashcroft that 'the Second Amendment protects an individual right to keep and bear arms'; and the recommendation of the 1999 UN Panel of Governmental Experts to argue that such matters are 'properly left to individual member states' (Bolton, 2001). If this particular action corresponds most closely to compulsory power (directly asserting power over the possible outcomes of the process), it did so by translating the productive power of the UN Panel, the NRA, and existing national law in a setting characterised by the absence of clear international law. More importantly, what gave this translation of powers its force was a key aspect of institutional power at work in the UN SALW process: the consensus rule.

Multilateral arms control, unlike International Humanitarian Law, tends to operate on the basis of a consensus rule. This may be written into the rules of procedure, or operative due to precedent and common expectations within the 'community of practice' of arms control diplomats (as in the Convention on Certain Conventional Weapons (CCW) framework) (Borrie and Thornton, 2008). Through consensus rules structural and institutional powers combine to produce (productive power) the conditions of possibility for particular configurations of compulsory power. In principle, the consensus rule diminishes the relativity of compulsory power, or of majoritarian imposition, by enabling every state a de facto veto (that is accompanied by an unwritten rule that vetoes will only be used in extreme situations (Caughley, 2012)). This procedural inheritance can prove limiting and in HAC institutional shifting (a different decision) beyond the CCW into separate processes (Ottawa and Oslo) enabled stronger agreements. Analyses of the Ottawa and Oslo processes highlight that this shifting to fora unencumbered by the consensus rule allowed a different tone to negotiations, a shift in the burden of proof to anti-control positions, and allowed proposals that would have 
weakened the agreements to be excluded - even though formal voting was not actually used (Goose and Williams, 2004; Rappert and Moyes, 2009).

The UN SALW process was shaped by this experience but has maintained its fragile unity by inhabiting the indeterminate space between consensus and majority. Indeed, the ability to oscillate between consensus rules and voting procedures (rather than inherent characteristics of either) gave the operations of institutional and compulsory power their particular character and demonstrates their co-constitution. The 1997 Panel of Governmental Experts that called for the 2001 UN Conference was split between those wishing to be within the UN system and those inspired by the rapid success of Ottawa. Rather than being set by the boundaries or character of the issue itself, it was the potential for a precedent being set by taking disarmament issues outside of the UN as well as a preference for consensus that ultimately pulled the conference towards the UN. Anticipating the need for consensus within this framework led to the removal of controversial language in draft PoAs during the three preparatory committees (Atwood and Greene 2002). The 2001 Conference proceeded on the basis of consensus but the rules of procedure allowed for voting (which required a two-thirds majority for substantive issues and a majority for procedural issues). These rules of procedure have been adopted, verbatim, in later meetings, including six Biennial Meetings of States (BMS) (2003, 2005, 2008, 2010, 2014, 2016), two Review Conferences (2006, 2012) and two Meetings of Governmental Experts (MGEs) (2011, 2015).

Outcome documents have mostly been agreed by consensus - though they are usually weaker for it. However, consensus was nearly abandoned in the 2005 Open Ended Working Group (OEWG) that negotiated the International Tracing Instrument (Batchelor and McDonald, 2005); and collapsed in the latter part of the 2006 Review Conference when US redlines reappeared (allowing other objectors to be more muted) and prevented agreement of an 
outcome document. In the latter, important developments had achieved wide support and were reinstated by votes in the UNGA First Committee (on the continuation of a series of BMS and a review conference; conventional ammunition stockpiles; and the negotiation of an ATT) each of which passed with only one vote against (the USA). After consensus rules generated this failure that appeared to jeopardise the continuation of the UN SALW process voting became more common with the outcome of the 2008 Biennial Meeting of States adopted by a vote. ${ }^{\text {vii }}$ By 2009 consensus returned in the unanimous adoption of that years 'omnibus' SALW resolution in the UNGA and has remained - though often as a fragile and last minute achievement in subsequent meetings. Overall, then consensus holds sway as the preferred principle of the SALW process with strategic use of voting procedures used principally to stabilise and protect the process. It is not, however, set in stone and Ambassador McLay (2014), chair of the 2011 MGE, argues that many states wishing to pursue legally binding agreements still consider moving beyond the consensus rules of the UN framework.

Similar oscillations between consensus and voting rules characterise the assembling of the legally binding 2013 ATT. The momentary abandoning of consensus in 2006 enabled the US blocking moves to be overcome; but when the US position began to shift with the Obama administration in 2009 it made its participation conditional upon negotiations operating on the basis of consensus. Likewise, Russia and China, which had abstained from the 2006 First Committee vote and the 2009 resolution that began the ATT process, were brought in to the process through the agreement of consensus rules and the shift in US position (though ultimately neither signed the treaty) (Wood, 2012). ${ }^{\text {viii }}$ Indeed, China softened its position on issues of IHL and Human Rights but was resolute on the need for consensus (Stavrianakis and Yun 2014). 
In oscillating between de facto vetoes and voting, and in the ways in which different forms of power are used to reinstate and enact - not just resist - others, the meaning of consensus was itself opened to contestation. This was particularly explicit in the ATT preparatory conferences, especially the fourth in February 2012 where some states supported a rigid consensus rule while others argued that in UN practice 'consensus is not synonymous with unanimity' and thus that it does not necessarily imply a veto power (Sears 2012: 45). Such ambiguity over consensus returned at the end of the March 2013 negotiating conference when the Mexican delegation attempted to head-off blocking moves by Iran, Syria, and DPRK by arguing that the overwhelming majority of states stood ready to adopt the treaty text as it was and that it should be adopted since 'there is no definition of what consensus is in the United Nations' (Gomez Robledo, 2013). This move failed, but a number of key states (including the US) took the text to a vote in the General Assembly which passed overwhelmingly. ${ }^{\text {ix }}$ Thus both the oscillation between consensus and voting, and attempts to posit an ambiguity in the meaning of consensus, have been central to maintaining momentum in the SALW and ATT processes.

The SALW process has also been maintained by shifting between more overtly political and more technically framed engagements that may represent structural power. After the acrimonious failure of the 2006 Review Conference, and amid disappointment that the first round of meetings in the PoA process (BMS 2003, BMS2005, and 2006 Review Conference) were utilised for basic reporting with no substantive outcomes, later BMSs adopted more issue-specific foci on brokering and stockpile management that enabled elaboration of conditions for effective implementation. More broadly Panels, Groups, and Meetings of Governmental Experts feature significantly and have enabled elaboration of issues such as brokering, ammunition, and the ATT. Such expert groups have been a creative site of action on issues central to the PoA but that did not achieve consensus or strong elaboration within 
the main process. For instance, while the US consistently blocked the inclusion of ammunition in the PoA process and expressed scepticism about a proposal for a separate UN process; the EU and others were able to support progress on ammunition through a 2008 GGE and parallel practices of technical standardisation. Further, since 2009 a number of Open-Ended Meetings of Governmental Experts (MGE) have been convened to address implementation challenges beyond the cycle of BMS's and Review Conferences. Such shifts of framing and focus towards technical issues, and thus to parallel political spaces based on technical expertise (authorised and populated by governments) rather than full UNGA consensus, has been essential to shifting operations of power to maintain coherence and trajectory of the process.

A shift to technics should be viewed as a move to a different constellation of politics rather than entirely depoliticising. GGEs, for instance, enable greater time for discussion (BMS's and Review Conferences include little time for negotiation rather than formal statements, leading to one estimate that the time available for negotiation of an outcome document in the 2006 review conference amounted to 20 hours (Prins, 2006)). They also contribute to the reinforcing of sovereignty within the process: GGEs are formally the preserve of states, though NGO personnel and researchers have been included in national delegations both the broad UN process and the variety of GGEs. Since GGEs are often tasked with elaborating responses and assessing feasibility of the constitution of regulatory action this shapes which actors may claim authority on particular questions: For some NGOs it is principally questions of the problem to be solved; for others (industry for instance) it is questions of the feasibility of controls (as in the UN process on Marking and Tracing small arms, and others). However, only states (and some inter-governmental organisations) speak with seeming authority on all of these issues. Thus, GGEs combine the productive power of expertise, the structural power of sovereignty, and the institutional power of decision making rules. As with the meaning of 
consensus, within these processes what counts as a technical or a political issue is produced through contestation.

Regime theory and studies of transnational governance often assume that the development of transnational or international governance proceeds through and has the effect of reducing degrees of disagreement and establishing procedures and rules through which issues are managed. Indeed, this Weberian rationalisation underlies claims that issue complexity resists regime formation. However, 'consensus' is an ambiguous concept whose meaning and necessity is formed through powerful controversies at multiple scales. The SALW assemblage, then, is not simply a site of homogenisation but the formation of a 'shifting surface on which disputes can foment and acquire significance’ (Barry, 2012: 328).

\section{MAKING ACTION POSSIBLE AND GUNS GOVERNABLE: MODES OF ACTION} AND THE PROLIFERAITON OF OBJECTS FOR COOPERATION

It is common to think that there must be agreement before action. How, then, is this shifting topology of proliferating disagreements, emergent powers, and partial stabilisations productive of governing guns? The classic problem of action at a distance comes into play here as it underlies taxonomies of powers (Barnett and Duval, 2005), regime theory and studies of SALW. The question of how the SALW assemblage makes guns governable is often engaged through questions about norm diffusion (Garcia, 2006). Thus, it is argued that some norms - such as surplus weapons disposal through destruction rather than export - gain ‘independent momentum’ (Karp, 2008: 77) while others change as they move, with change being a function of local resistance and reformulation (Capie, 2008) or the context specific ways in which they enter complex contestations about state-society relations (Tholens, 2013). This literature captures dimensions of the diversity and mutability of SALW 'norms' but 
what constitutes their stability? How are they translated into forms of action on guns? I argue that norms are not just ideas that are agreed and then diffused since, as Walters (2002: 92) notes, 'ideas are not always strong enough or persistent enough' to produce actions. Rather they are materialised, translated in sets of practices. The SALW assemblage cannot be the triumph of an idea, nor only the creation of a set of 'norms', but must be a set of materialised practices that compose particular modes of action.

As Krause argues, contemporary arms control - particularly in HAC and SALW control - is a hybrid of sovereignty and governmentality in which the agendas of arms control have extended beyond the interstate into state-society relationships. In doing so, he argues, it draws on 'well-established understandings of what is involved in controlling arms (sovereignty), while deploying the logic (and practices) of governmentality to regulate a fundamental aspect of the relationship between states and their citizens.' (2011: 32). This is often depoliticising, and indeed operates in part by denying and obscuring its own political nature. Indeed, it is something of a paradox that the most obviously political implications of SALW control are often achieved through anti-political forms of technocratic engagement. This is partly explained by the emphasis on a particular logic of governing in the SALW assemblage: that of risk. Risk has become the dominant governmental logic of action throughout HAC, though it takes very different forms. When HAC centres on the weapon itself it has tended to adopt a precautionary approach that leads to clear prohibitions for APM and Cluster Munitions. However, as an effect of the genotype and forms of power of the SALW assemblage, a permissive logic (focussing on the illicit trade, or enacting some limited grounds for prohibition and restraint on the basis of 'overriding risk' in the ATT). This permissive logic channels action into risk management through ensuring the governability of weapons stocks and flows (through stockpile management, marking and tracing, DDR etc.) while reinforcing sovereign decision and systems of trade and use. 
The problem of action at a distance remains, but in addition to looking at how norms cross geographical or temporal distance can be engaged topologically, since in topology spatiality is an emergent and shifting set of relations of proximity and distance. How are geographically distant actors and weapons rendered functionally proximate within the SALW assemblage? Perhaps the most common mode of action, across global and regional agreements and processes on SALW, is standardisation and harmonisation and associated technical and financial assistance. Standardisation practices are constituted through, and extend, the relations of mutual authorisation, expertise, and techno-politics explored earlier: that is 'productive power' can be seen to operate not only through the creation of 'subject positions' (Barnett and Duvall, 2005) but of wider modes of action that tie together new spatialities of governing.

Such technical practices have been a more consistent and extensive feature of the SALW assemblage than some classic dimensions of arms control politics such as verification since this has proved highly divisive in HAC and thus is largely excluded from formal outcomes. NGO and researcher monitoring has compensated for this in wider HAC with the Landmine Monitor reports building on and reinforce the moral authority of some NGOs (Wareham, 2008). In the SALW assemblage, PoA monitoring through the Biting the Bullet project/IANSA 'Red Book' reports (for BMS 2003, BMS 2005; and the 2006 Review Conference); ${ }^{\mathrm{x}}$ and analyses by UNIDIR and SAS attempted to emulate some of this success. However, such initiatives have largely been discontinued due to lack of funding. Instead, a set of relations more attuned to developing functional rather than overtly political information infrastructures have been developed through baseline assessment frameworks for ATT implementation, and the development of indicators for assessing the SDGs - thus becoming more attuned to functional standardisation as a mode of action. 
International standards enable power to act at a distance (this is their primary function). Importantly they do this through being productively powerful. Standards are 'objects for cooperation' (Bowker and Star 2000: 16) that enable the production of global action. Importantly, standards do not need to eradicate the diversity of issues and positions; but reduce them and their tensions in a functional unity (an assemblage). That is, they are 'boundary objects' which draw together action across boundaries and distances forming part of the unifying topology of powers in the SALW assemblage. As Bowker and Star argue of standards more generally, they:

'inhabit several communities of practice and satisfy the informational requirements of each...they are objects that are able both to travel across borders and maintain some sort of constant identity across sites. They are weakly structured in common use and become strongly structured in individual-site use.' (2000: 297).

Standards are powerful objects that are productive of novel spaces, that Barry calls 'technological zones': 'space[s] within which differences between technical practices, procedures or forms have been reduced, or common standards have been established' (2006: 239). Such zones are important aspects of the infrastructure of transnational governance and global assemblages (Ong and Collier, 2005). ${ }^{\mathrm{xi}}$ They are formed by techniques that render issues technical rather than political, that seek to remove and reshape contestation (though only ever provisionally and incompletely).

Standardisation operates through inscriptions to render SALW governable but also sustain the relative autonomy of sovereign decision. As noted earlier, for Rose and Miller 'The inscriptions of the world which an individual or a group can compile, consult or control play a key role in the powers they can exercise' (1992: 185-6). Inscription here is literal not 
metaphorical: Governing depends on writing, making marks, and circulating them in particular ways to render phenomena governable. Further, the circulations of standards are the conditions of possibility of governing. This is most clearly seen in the 2005 International Marking and Tracing Instrument (ITI) that standardises the markings (literal inscriptions) to be placed on weapons and the associated recordkeeping and information exchange thereby rendering weapons and their circulation governable globally (if not necessarily well governed). Indeed, international assistance to provide marking machines and inventory software, such as those provided in Central Africa and beyond through the Regional Centre on Small Arms (RECSA), or in the Balkans by SEESAC xii extends the capacity make inscriptions that can be compared for identification and tracing purposes. Thus inscribing the possibility of control onto weapons and databases makes the life-cycle of guns more amenable to governing.

More widely, standardisation is a modality of action that connects the UN process with the wider SALW assemblage and enables the development of practices beyond the minimal letter of the lacklustre PoA. Many standards, such as Best Practice Guidelines produced by the OSCE and the Wassenaar Arrangement, or a detailed procedural 'users guide' for the EU Common Position, are not simply ‘implementation’ of norms and commitments agreed in global fora, but rather specific techniques of international action that have been extended and framed by that global process. The ongoing development of International Small Arms Control Standards (ISACS) first launched in 2012 draws upon many of these as well as experiences of diverse UN agencies and is partly inspired by the success of International Mine Action Standards and the 2006 UN Integrated Disarmament Demobilisation and Reintegration Standards (IDDRS) (Bourne and Greene 2012). As above, it is mutual authorisation and shift to technics that produces potentially powerful objects for cooperation - including in areas resistant to wider global political agreement. For instance, the 2008 GGE 
on ammunition fed into the development of the UN SaferGuard programme for ammunition stockpile management that combines the political authority of UNGA mandates with empirical research evidence from the Small Arms Survey, and technical expertise from ammunition experts who vetted the guidelines.

Once assembled the power of such standards lies in their circulation, in this case again reinforcing the power of the UN who provide training, software and other assistance. Likewise, the UN gains authority in channelling NGO and researcher advice and resources alongside UNODA and other organization materials in the PoA Implementation Support System and emerging resources for the ATT (http://www.poa-iss.org/Poa/poa.aspx; http://www.un.org/disarmament/ATT/). National implementation in many countries features the conduct of national small arms assessments by NGOs and research organisations to inform national strategies, and now more globally distributed software-based assessment tools from ISACS. Similarly, practices of legislative reform, are held together through the production of model laws such those developed by the OAS or the 182 page Model Law on firearms trafficking produced by the UNODC that incorporates standards and commitments from a wide range of other agreements and best practices. Such models provide elaboration and meaning to notions of risk- even on issues of civilian possession that proved impossible to agree in the formal PoA process as some ISACS standards (UN CASA, 2015).

Overall, therefore, the mode of action of standardisation combines both the agreements and disagreements, the mutual authorisations and intersections of forms of power by further shifting the spaces of contestation and information. Rather than seeing such materialisation of standardisation as an indicator of the prior strength (or weakness) of the norm, I argue that materialisation is the process of norms becoming strong (durable, mobile, extensive etc.). The implications of the production and circulation of technical standards for understanding power 
would be missed if they were viewed simply as attempts to implement wider norms. Assemblage thinking, however, speaks of functional symbiosis rather than normative uniformity. Thus, a regime as an assemblage becomes a question of co-functioning and coproduction. The proliferation of standards does not merely compensate for the lack of detail in the UNPoA or other multilateral agreements, but rather is the process through which the forms of power forged in (dis)agreement are productive of global spaces and possibilities of action.

\section{CONCLUSION}

Viewed in the traditional sense of a 'regime' global SALW politics is frequently disappointing in its scope, strength, and capacity to address armed violence. This disappointment should not disappear with the view developed here. Rather, it is given a different register in which instead of working through linear cause and effect of norm creation, diffusion and action seeks the achievement of possibility and power. Assemblage thinking is inherently more indeterminate than much regime thinking, but this indeterminacy is an ontological condition worked through rather than a reflection of the weakness of normative cause or the strength of structural and compulsory power. This allows recognition that a regime is an assemblage of controversies as much as a settlement of them, giving a different view of what it means to establish a provisional unity in collective action and action at a distance. It is the production of a topological political space (not Euclidean geometry), the creation of possibilities, modes of power, (dis)agreement, and action.

Powers emerge within composing assemblages. Rather than disjointing power, parsing it into settled forms with particular properties (defined by a prior spatiality or separation of the constitutive from the interactive) assembling the processes of powers unsettles and dynamises notions of power in 'regimes'. Thus, rather than explaining the possibilities of global SALW 
control through forms of powers with given properties, powers and possibilities are coemergent. Particular forms of power are intra-actively constituted by others: For instance, compulsory power, so evident in the founding moments of the PoA, is composed by particular intra-actions of rules, preferences, forms of evidence, associations of mutual authorisation normally viewed as part of other forms of power. In connecting powers productively in process the distinctions between them are not erased. Assemblages retain and articulate differences, but differences are made to matter in process: For instance, the oscillation between experts and states, consensus and voting, or traditional politics and technics, shows that the assemblage functions through enabling controversies, channelling and shifting between frames, and proliferating objects for cooperation.

The strength of the SALW assemblage lies not initially, nor even predominantly, through forging normative agreement, but in making a political space constituting and constituted by the possibility to disagree; this is an informational infrastructure that invites attention to the circulations and mutual authorisations that constitute powerful actors and actions and establish the terms and forms of disagreement. Moreover, this is not a static picture but a moving one: It therefore argued that the functional unity, indeed the continued existence, of the UN SALW process was the effect of two principle forms of oscillation: between consensus and majority; and between formally political and technical settings. In this process the content and meanings of agreement and decision are co-emergent. Both disagreement and agreement operate through inscriptions that pull together and shift between different settings; and thus so does the mode of action through which the SALW assemblage has reproduced itself and has sought to make the world in its own image to make guns governable.

\section{REFERENCES}


Atwood, D. and Greene, O. (2002) Reaching Consensus in New York: The UN 2001 Small Arms Conference. In P. Batchelor and K. Krause (eds.) Small Arms Survey 2002: Counting the Human Cost, Oxford: Oxford University Press: pp. 203-233.

Barad, K. (2007) Meeting the Universe Halfway: Quantum Physics and the Entanglement of Matter and Meaning Durham: Duke University Press.

Barnett, J. and Finnemore, M. (1999) The Politics, Power, and Pathologies of International Organizations. International Organization 53(4): 699-732.

Barnett, M. and Duvall, R. (2005) Power in International Politics. International Organization 59(1): 39-75.

Barry, A. (2006) Technological Zones. European Journal of Social Theory 9(2): 239-253.

Barry, A. (2012) Political situations: knowledge controversies in transnational governance, Critical Policy Studies 6(3):324-336.

Barry, A. (2013) Material Politics: Disputes Along the Pipeline. Oxford: Wiley-Blackwell.

Batchelor, P. and McDonald, G. (2005) Too close for comfort: an analysis of the UN tracing negotiations. Disarmament Forum 2005(4):39-47.

Bob, C. (2010) Packing heat: pro-gun groups and the governance of small arms. In D. Avant, M. Finnemore, and S.K. Seil (eds.) Who Governs the Globe Cambridge: Cambridge University Press: pp. 183-201.

Bolton, J.R. (2001) U.S. Statement at Plenary Session Under Secretary of State for Arms Control and International Security Affairs UN Conference on the Illicit Trade in 
Small Arms and Light Weapons in All its Aspects July 9, 2001. At: http://www.fas.org/asmp/campaigns/smallarms/SAconf-USstmt.htm

Borrie, J. (2009) Unacceptable Harm: A History of How the Treaty to Ban Cluster Munitions Was Won. Geneva: UNIDIR.

Borrie, J. and Thornton, A. (2008) The Value of Diversity in Multilateral Disarmament Work, Geneva: UNIDIR.

Bourne, M. and Greene, O. (2012) Governance and Control of SALW after armed conflicts. in O. Greene, and N. Marsh (eds.) Small Arms, Crime and Conflict: Global governance and the threat of armed violence, London: Routledge: 183-206.

Bourne, M., Godnick, B., Greene, O., Kirkham, E., Macalesher, J., Vivekananda, J., and Watson, C. (2006) Reviewing Action on Small Arms 2006: Assessing the first five Years of the UN Programme of Action, London: Biting the Bullet and IANSA.

Bowker, G. and Star, S.L. (2000) Sorting things out: classification and its consequences Massachusetts: MIT Press.

Capie, D. (2008) Localization as resistance: The contested diffusion of small arms norms in Southeast Asia. Security Dialogue 39(6): 637-658.

Caughley, T. (2012) The Elusive Consensus. At http://www.acronym.org.uk/articles-andanalyses/elusive-consensus.

Collier, S.J. and Ong, A. (2005) Global Assemblages, Anthropological Problems. In A. Ong, and S.J. Collier (eds.) Global Assemblages: Technology, Politics, and Ethics as Anthropological Problems Oxford: Blackwell Publishing: 3-21. 
Cooper, N. (2011) Humanitarian Arms Control and Processes of Securitization: Moving Weapons along the Security Continuum. Contemporary Security Policy 32(1): 134158.

Deleuze, G. and Parnet, C. (2007) Dialogues II. Columbia: Columbia University Press.

Drezner, D.W. (2008) All politics is global: explaining international regulatory regimes Princeton: Princeton University Press.

Efrat, A (2010) Toward Internationally Regulated Goods: Controlling the Trade in Small Arms and Light Weapons, International Organization 64 (winter 2010):97-131.

Eyal, G. and Pok, G. (2015) What is security expertise? From the sociology of professions to the analysis of networks of expertise. In T.V. Berling and C. Bueger (Eds) Security Expertise: Practice, Power Responsibility London: Routledge: 37-59.

Florini, A. (1996) The Evolution of International Norms. International Studies Quarterly 40(3):363-389.

Garcia, D. (2006) Small Arms and Security: New emerging international norms, London: Routledge.

Garcia, D. (2011) Disarmament Diplomacy and Human Security: Regimes, norms and moral progress in international relations London: Routledge.

Garcia, D. (2015) Humanitarian Security Regimes. International Affairs 91(1): 55-75.

Geneva Declaration Secretariat (2015) Global Burden of Armed Violence 2015: Every Body Counts, Cambridge: Cambridge University Press. 
Gomez Robledo, Amb. J.M. (2013) Statement by Amb. Juan Manuel Gomez Robledo, Head of Delegation of Mexico, Final UN Conference on the ATT. 28 March 2013. http://reachingcriticalwill.org/images/documents/Disarmament-fora/att/negotiatingconference-ii/statements/28March_Mexico.pdf

Goose, S. and Williams, J. (2004) The Campaign to Ban Antipersonnel Landmines: Potential Lessons. In R.A. Matthew, B. McDonald, and K.R. Rutherford (eds.) Landmines and Human Security: International Politics and War's Hidden Legacy, Albany: State University of New York Press: 239-50.

Greene, O. and Marsh, N. (2012) Governance and small arms and light weapons. In O. Greene and N. Marsh (eds.) Small Arms, Crime and Conflict: Global governance and the threat of armed violence London: Routledge: 163-182.

Grillot, S.R., Stapley, C.S. and Hanna, M.E. (2006) Assessing the Small Arms Movement: The trials and tribulations of a transnational network. Contemporary Security Policy, 27(1):60-84.

Hansen, S.T. (2016) Taking ambiguity seriously: Explaining the indeterminacy of the European Union conventional arms export control regime European Journal of International Relations 22(1):192-216.

Hansen, H.K. and Porter, T. (2012) What Do Numbers Do in Transnational Governance? International Political Sociology, 6(4):409-426.

Hofmann, GP. and Wisotzki, S. (2014) Global Governance Efforts in Tension between Humanitarian Concerns and Statist Sovereignty Rights, International Negotiation, 19(3): 487-517. 
Holtom, P., Pavesi, I., and Rigual, C. (2014) Trade Update. In G. McDonald, E. LeBrun, A. Alvazzi del Frate, E.G. Berman, and K. Krause (eds.) Small Arms Survey 2014: Women and Guns, Cambridge: Cambridge University Press: 109-143.

Hubert, D. (2000) The Landmine Ban: A Case Study in Humanitarian Advocacy, The Thomas J. Watson Jr. Institute for International Studies Occasional Paper \#42. Available at http://www.watsoninstitute.org/pub/op42.pdf

Karp, A. (2002) Laudable Failure. SAIS Review XXII(1): 177-93.

Karp, A. (2008) A Semi-automatic Process? Identifying and Destroying Military Surplus. In E. Berman, K. Krause, E. LeBrun, and G. McDonald (eds.) Small Arms Survey 2008: Risk and Resilience, Cambridge: Cambridge University Press: pp. 77-111.

Krause, K. (2001) Norm-Building in Security Spaces: The Emergence of the Light Weapons Problematic, http://www.academia.edu/2696290/Normbuilding_in_security_spaces_The_emergence_of_the_light_weapons_problematic

Krause, K. (2011) Leashing the dogs of war: Arms Control from Sovereignty to Governmentality. Contemporary Security Policy 32(1):20-39.

Latour, B. (1986) The Powers of Association. In J. Law (ed.) Power, Action and Belief: a New Sociology of Knowledge? London: Routledge. pp 264-280.

Latour, B. (2005) Reassembling the social: An introduction to Actor-Network Theory, Oxford: Oxford University Press.

Laurance, E.J. (2014) The small arms problem as arms control: a policy driven agenda. In P. Batchelor and K.M. Kenkel (eds.) Controlling Small Arms: Consolidation, Innovation and Relevance in Research and Policy, Abingdon: Routledge: 13-35. 
Marres, N. (2007) Pragmatist Contributions to the Study of Public Involvement in Controversy. Social Studies of Science 37(5):759-780.

Mathur, R. (2012) Practices of Legalization in Arms Control and Disarmament: The ICRC, CCW and Landmines. Contemporary Security Policy 33(3):413-436.

McDonald, G. (2013) Worth the Paper? The Arms Trade Treaty. At http://www.eir.info/2013/04/17/worth-the-paper-the-arms-trade-treaty/

McDonald, G. (2014) Measures: informing diplomacy - the role of research in the UN small arms process. In P. Batchelor and K.M. Kenkel (eds.) Controlling Small Arms: Consolidation, Innovation and Relevance in Research and Policy, Abingdon: Routledge: 150-71.

McLay, J. (2014) Beyond stalemate: advocacy and action in the UN small arms process. In P. Batchelor and K.M. Kenkel (eds.) Controlling Small Arms: Consolidation, Innovation and Relevance in Research and Policy, Abingdon: Routledge: 286-301

Mutimer, D. (2006) 'A serious threat to peace, reconciliation, safety, security’: An effective reading of the United Nations Programme of Action. Contemporary Security Policy 27(1):29-44,

Ong, A. and Collier, S.J. (eds.) (2005) Global Assemblages: Technology, Politics, and Ethics as Anthropological Problems Oxford: Blackwell Publishing.

Prins, D. (2006) Engineering Progress: A Diplomat's Perspective on Multilateral Disarmament. In J. Borrie and V.M. Randin (eds.) Thinking outside the Box in Multilateral Disarmament and Arms Control Negotiations Geneva: United Nations Institute for Disarmament Research: pp. 109-127. 
Prokosch, E. (1995) The Technology of Killing: A Military and Political History of AntiPersonnel Weapons. London: Zed Books.

Rappert, B. and Moyes, R. (2009) The Prohibition of Cluster Munitions: Setting International Precedents for Defining Inhumanity. The Nonproliferation Review 16(2):237-56.

Rogers, D. (2009) Postinternationalism and Small Arms Control: Theory, Politics, Security. Farnham: Ashgate.

Rose, N. and Miller, P. (1992) Political Power beyond the State: Problematics of Government. The British Journal of Sociology 43(2):173-205.

Sears, N.A. (2012) Controlling Small Arms and Light Weapons Proliferation: The Potential of the Arms Trade Treaty. Patterson Review of International Affairs 12:35-60.

Serres, M. and Latour, B. (1995) Conversations on science, culture and time. Ann Arbor: University of Michigan Press.

Stavrianakis, A. (2011) Small Arms Control and the Reproduction of Imperial Relations. Contemporary Security Policy 32(1):193-214.

Stavrianakis, A. and Yun, H. (2014) China and the Arms Trade Treaty London: Saferworld.

Stengers, I. (2000) The invention of modern science. Minneapolis: University of Minnesota Press.

Strange, S. (1982) Cave! Hic Dragones: A Critique of Regime Analysis. International Organization 36(2):479-496. 
Tholens, S. (2013) Localization Strategies in Post-War Security Governance: Bringing in State-Society Narratives. Paper presented at the International Studies Association annual conference, San Francisco, April 3-6, 2013. Cited with permission.

UN (2013) Arms Trade Treaty Will Generate ‘Much-Needed Momentum’ for Other Global Disarmament, Non-proliferation Efforts, Secretary-General Says’ UN Press Release SG/SM/14919-DC/3426; $\quad 2^{\text {nd }} \quad$ April $2013 . \quad$ At http://www.un.org/press/en/2013/sgsm14919.doc.htm (last accessed 22/3/16).

UN CASA (2015), International Small Arms Control Standard 03.30: National Regulation of Civilian Access to Small Arms and Light Weapons, http://www.smallarmsstandards.org/isacs/0330-en.pdf (last accessed 17/1/17)

Walters, W. (2002) The Power of Inscription: Beyond Social Construction and Deconstruction in European Integration Studies. Millennium Journal of International Studies 31(1):83-108.

Walters, W. and D'Aoust, A, (2015) Bringing Publics into Critical Security Studies: Notes for a Research Strategy. Millennium Journal of International Studies 44(1):45-68.

Wareham, M. (2008) Evidence-Based Advocacy: Civil Society Monitoring of the Mine Ban Treaty. In J. Williams, S.D. Goose and M. Wareham (eds.) Banning Landmines: Disarmament, Citizen Diplomacy, and Human Security Lanham: Rowman \& Littlefield: pp. 49-68.

Whitehead, A.N. (1929/1978) Process and Reality: Corrected Edition. New York: The Free Press. 
Wisotzki, S. (2010) Between Morality and Military Interests: Norm setting in humanitarian arms control. PRIF Report No.92. Frankfurt: Frankfurt Peace Research Institute.

Wood, A. (2012) How to Reach Consensus on an Arms Trade Treaty. Arms Control Today, January $12 \quad 2012 . \quad$ http://www.armscontrol.org/act/2012_0102/How_to_Reach_Consensus_on_an_Arms_Trade_Treaty

\footnotetext{
${ }^{\mathrm{i}}$ The author is grateful for reviewer comments and those of colleagues at conferences (International Studies Association 2015) and workshops (Prague) on earlier drafts of this article. The work for this article was supported by the Global Prohibition Regimes: Theoretical Refinement and Empirical Analysis grant from the Grant Agency of the Czech Republic (GA13-26485S) held by the Institute of International Relations, Prague. The views expressed and any errors are the author's own.
}

\footnotetext{
ii Based on an estimated 197,000 killings per year, accounting for over $44 \%$ of the 508,000 deaths between 2007 and 2012

iii This appreciates but troubles the organising principles of Barnett and Duval's taxonomy. Organising types around whether relations of power work directly (compulsory and structural power) or indirectly (institutional and productive power) emphasises positionality in a relatively stable set of relations. Instead, topology looks to the shifting of the direct (proximate) and indirect (distant); while also engaging the problem of the constitution of action at a distance and the relative mutability or immutability of objects (e.g. norms, procedures) as they move.
}
${ }^{\text {iv }}$ For Latour et-al "The word "controversy" refers here to every bit of science and technology which is not yet stabilized, closed or "black boxed" ... we use it as a general term to describe shared uncertainty”. (Macospol, 2007: 6, emphasis in original)

${ }^{v}$ Barad clarifies this when she says 'Agency is a matter of intra-acting; it is an enactment, not something that someone or something has. It cannot be designated as an attribute of subjects or 
objects (as they do not pre-exist as such). It is not an attribute whatsoever. Agency is "doing" or “being” in its intra-activity. It is the enactment of iterative changes to particular practices.' (2007: 178).

vi The Inter-American Convention Against the Illicit Manufacturing of and Trafficking in Firearms, Ammunition, Explosives, and other Related Materials.

vii Passing with 134 votes for, none against, and abstentions from Iran and Zimbabwe; though many states were absent - most notably the US (http://www.un.org/press/en/2008/dc3124.doc.htm).

viii The rules of procedure that applied in both attempts to negotiate the ATT, at conferences in 2012 and 2013, required consensus on substantive matters. Procedural matters could be put to a vote if consensus failed (UN 2012).

ix 155 votes in favour, 3 votes against and 22 abstentions.

${ }^{x}$ See for example, Bourne et-al 2006. The Biting the Bullet project was a coalition of two NGOs (Saferworld, International Alert) and the University of Bradford.

xi Barry argues that technological zones may be 'metrological zones' (formed of and through techniques of monitoring and measurement); 'infrastructural zones' (related to common connection standards); or 'zones of qualification' which ‘come into being when objects and practices are assessed according to common standards and criteria' and that are often predicated on transparency mechanisms (Barry, 2006: 239).

xii UNDP South Eastern and Eastern Europe Clearinghouse for the Control of Small Arms and Light Weapons (SEESAC) 